\title{
Digitalization in a resource-extracting region: from cluster to business ecosystem
}

\author{
Evgeny Zhernov ${ }^{1 *}$, Evgenia Nekhoda $^{2}$, and Iryna Rusak $^{3}$ \\ ${ }^{1}$ T.F. Gorbachev Kuzbass State Technical University, Department of Economics, 650000 Kemerovo, \\ 28 Vesennyaya St., Russian Federation \\ ${ }^{2}$ National Research Tomsk State University, Department of Strategic Management and Marketing, \\ 634050 Tomsk, 36 Lenin Ave., Russian Federation \\ ${ }^{3}$ Academy of Public Administration under the President of the Republic of Belarus, Department of \\ Organization Economics, 220007 Minsk, 17 Moskovskaya St., Belarus
}

\begin{abstract}
The purpose of the study is to trace the evolution of the mineral resource cluster in a resource-extracting region from a territorial association of entities in the industrial economy to a business ecosystem in the digital economy within the framework of the sustainable development concept. The urgency of the research is due to the increase in the information and knowledge intensity of a product in the digital economy, which makes the cluster policy based on the digital principle more efficient than that based on the territorial principle. The digitalization of the mineral resource sector of a resource-extracting region, started with a cluster - a progressive organizational and managerial form - is seen by the authors as a strategic means of increasing the sustainability and efficiency of the socio-economic development of a region. The delegation of responsibility for the modernization of the economy to the regional level gives particular importance to regional research. The dependence on the state of the world market of fuel and energy resources, the exhaustion of the mainly raw material export model of economic growth put Kuzbass, the mining region of Western Siberia, in the most difficult situation. The issue of accelerating the transition to an innovation resource type of development through structural and technological transformation in the context of the general course towards digitalization is urgent for it. A theoretical substantiation of the necessity, possibility and feasibility of digitalization of the mineral resource cluster as a factor in the sustainable development of a resourceextracting region is presented in the article.
\end{abstract}

\section{Introduction}

The research object is real and potential mineral clusters of a resource-extracting region as digital business ecosystems.

The research subject is the evolution of the regional mineral resource cluster under the influence of digitalization processes.

\footnotetext{
*Corresponding author: zhee.eti@kuzstu.ru
} 
The goal of the research is achieved by scientifically substantiating the necessity, possibility and feasibility of digitalization of the mineral resource cluster for the sustainable development of a resource-extracting region.

To achieve this goal, tasks were formulated, the solution of which made it possible to obtain results of practical importance with the elements of scientific novelty:

1) to describe the digital aspects of the formation of the mineral resource cluster in the context of sustainable development;

2) to supplement the theory and methods of managing the sustainable development of digital business ecosystems, which, according to the authors, include the digital mineral resource cluster.

The scientific novelty of the research lies in the development of the concept of sustainable economic development in a cluster form as applied to resource-extracting regions at the present stage of their socio-economic development, determined by digitalization. The scientific significance lies in identifying the trend in the sustainable development of the mineral resource cluster from a territorial association to a digital business ecosystem on the example of the Kemerovo Region - Kuzbass - an important coal mining region of Western Siberia.

The practical significance of the research is associated with the possibilities of using the identified trends in the sustainable development of the mineral resource cluster in the substantiation, development and decision-making on strategic issues of the socio-economic development of resource-extracting territorial entities of the Russian Federation.

\section{Materials and Methods}

Economic assets and entities are digitalized within the framework of the information and knowledge paradigm of sustainable development, in which the statement "the economy is a managed system" is an axiom. It is even more true in relation to the digital economy - the modern stage of the knowledge economy. The production base of the digital economy is made up of digital enterprises. Mining companies operating on the principle of "smart open pit" and "smart mine" are unified information and management structures. In their circuit there is monitoring and management of the digital mining equipment system. From the point of view of economic theory and management, these enterprises belong to the category of "intellectual firm" of the knowledge economy [1,2]. In the context of the transition to the digital stage of the knowledge economy, the importance of management increases many times, new organizational and management forms that are adequate to digital technologies are required. Among them are globally recognized clusters [3, 4].

Being based on the information and management infrastructure, the "intelligent open pit", "smart open pit" are the production element of the business ecosystem $[5,6]$. The emergence of a new type of economy, the knowledge economy, characterizes a qualitative leap from the dominance of a technical and technological component to a structural and organizational one. Currently, this is actively manifested in the creation of business ecosystems [7]. In these ecosystems, "companies jointly develop capabilities around new innovation: they work together and competitively to support new products, meet customer needs, and ultimately drive the next wave of innovation" [8]. Examples of business ecosystems created by Apple, IBM, Ford, Wal-Mart and Merck, in Russia by Sberbank and MTS have become classic.

Three stages can be distinguished in theoretical works on clusters. At the first one, the emphasis was placed on increasing production efficiency through positive economies of scale, reducing transport and transaction costs, although the importance of knowledge exchange was noted $[9,10]$. 
At the second stage, primacy belonged to theories associating the creation of clusters with their advantage in innovation through the creation of non-marketable assets, high production efficiency and knowledge exchange, as well as in the transformation of knowledge into a commodity $[11,12]$. This stage corresponds to the formation of the knowledge economy.

The third stage naturally reflects the focus of the works on clustering on the digital economy [13, 14]. Although not all researchers [15] recognize this, increasing the information and knowledge intensity of a product makes cluster policy based on the digital principle more efficient than that based on the territorial principle $[16,17]$.

So, a review of the literature has shown that in modern works on the topic of the research, the trend in the development of a mineral resource cluster towards the business ecosystem of a resource-extracting region and the digitalization of its economy are often considered separately, without regard to sustainable development processes. Consequently, the task of theoretically substantiating the digitalization of a cluster in the form of a business ecosystem in the coal industry of a resource-extracting region for its sustainable development is poorly studied in economic science, and the identified aspect of the problem can be the beginning of a discussion and give new scientific and practical results.

\section{Results and Discussion}

The fundamental compatibility of economic growth and sustainable development is justified, among other things, by basing the former on new technologies. Digital technologies stand out among them today. In terms of environmentally efficient technologies, hopes hoping of improving the environmental situation in the resourceextracting region are also laid on them. The negative consequences for society of economic development, which is spontaneous in many respects, raise the question of controlled economic growth as the basis for achieving sustainable development. A cluster is recognized throughout the world as a modern organizational and economic form of such management. Let's conduct a comparative analysis of conventional cluster, digital cluster and business ecosystem (see Table).

Table. Comparative analysis of conventional cluster, digital cluster and business ecosystem

\begin{tabular}{|l|l|l|l|}
\hline \multicolumn{1}{|c|}{ Characteristic } & Conventional cluster & Digital cluster & Business ecosystem \\
\hline $\begin{array}{l}\text { The essence of the } \\
\text { type of organization }\end{array}$ & $\begin{array}{l}\text { Geographically } \\
\text { concentrated groups of } \\
\text { interrelated entities in } \\
\text { related industries that } \\
\text { compete but } \\
\text { collaborate }\end{array}$ & $\begin{array}{l}\text { The core of the } \\
\text { cluster, uniting } \\
\text { organizations } \\
\text { around itself, is } \\
\text { located in a } \\
\text { virtual digital } \\
\text { space, not tied to } \\
\text { a specific } \\
\text { geographic } \\
\text { location }\end{array}$ & $\begin{array}{l}\text { A dynamic and } \\
\text { jointly developing } \\
\text { community of } \\
\text { entities creating and } \\
\text { receiving new } \\
\text { content in the } \\
\text { process of interaction } \\
\text { and competition }\end{array}$ \\
\hline $\begin{array}{l}\text { Geographic factor } \\
\text { Knowledge }\end{array}$ & Fundamental \\
generation and \\
exchange quality
\end{tabular}




\begin{tabular}{|l|l|l|l|}
\hline & $\begin{array}{l}\text { but local } \\
\text { communication is an } \\
\text { incentive for } \\
\text { innovation }\end{array}$ & Territorial placement & $\begin{array}{l}\text { Digital } \\
\text { environment } \\
\text { technologies }\end{array}$ \\
\hline $\begin{array}{l}\text { Basis for the } \\
\text { integration of } \\
\text { cluster entities }\end{array}$ & $\begin{array}{l}\text { A single } \\
\text { technological } \\
\text { platform as a } \\
\text { knowledge resourcec }\end{array}$ \\
\hline Place of transactions & Territorial space & $\begin{array}{l}\text { Digital virtual } \\
\text { space }\end{array}$ & Digital virtual space \\
\hline Control concept & $\begin{array}{l}\text { Participants are legally } \\
\text { independent, } \\
\text { controlled by the one } \\
\text { who has a large market } \\
\text { share }\end{array}$ & $\begin{array}{l}\text { Controlled by the } \\
\text { founding } \\
\text { company } \\
\text { (keystone) }\end{array}$ & $\begin{array}{l}\text { Controlled by the } \\
\text { founding company } \\
\text { (keystone). High } \\
\text { probability of a } \\
\text { leader change }\end{array}$ \\
\hline $\begin{array}{l}\text { Sustainability } \\
\text { Sufficient }\end{array}$ & $\begin{array}{l}\text { Sufficient } \\
\text { Relative due to } \\
\text { constant internal } \\
\text { transformations }\end{array}$ \\
\hline $\begin{array}{l}\text { The role of } \\
\text { competition and } \\
\text { cooperation in } \\
\text { providing } \\
\text { innovation for } \\
\text { sustainable } \\
\text { development }\end{array}$ & $\begin{array}{l}\text { Competition between } \\
\text { participants is a source } \\
\text { of innovation }\end{array}$ & $\begin{array}{l}\text { Cooperation of } \\
\text { participants is a } \\
\text { source of } \\
\text { innovation }\end{array}$ & $\begin{array}{l}\text { Are equally } \\
\text { important: their } \\
\text { combination ensures } \\
\text { sustainable } \\
\text { development }\end{array}$ \\
\hline $\begin{array}{l}\text { Internal system of } \\
\text { economic relations }\end{array}$ & Hierarchy & Etharchy & Etharchy \\
\hline
\end{tabular}

The similarity between the classically understood cluster and the business ecosystem is that both of them are a set of interconnected organizations. The difference between them is that, as a rule, in the business ecosystem as a community there is an evident leader who sets the interaction rules. The conventional cluster assumes the presence of relatively equal participants, linked by their location in the same territory. With the development of new technologies, information, management and financial transactions within the cluster are increasingly moving to the digital environment, which means they are less dependent on the physical location of their participants. Due to an objective increase in the knowledge intensity of products currently produced by the enterprises of the cluster, such interactions become the center of its functioning. This provides sufficient stability.

At the moment, the term "business ecosystem" is used, as a rule, in relation to digital platforms that unite economic entities that produce and consume mainly information goods and services. But the meaning of the term is constantly expanding. R. Ayres notes that the purpose of the ecosystem is to improve the interaction of the company with its partners, increase the competitive advantage, expressed in the creation of innovative products that will be a leader in their industry. He rightly believes that companies need to innovate and build new relationships for a "healthy" ecosystem [18].

We consider it reasonable to introduce the concept of "digital cluster", since it organically combines the concepts of a business ecosystem and a cluster. This is due to the fact that the understanding of a cluster as a socio-economic system tied to a specific geographic area is losing its relevance as production and management are digitized. At the same time, unlike a business ecosystem, a digital cluster is not limited to an amalgamation 
of software and other information technology manufacturers. In addition, the main function of a digital cluster is to reduce the transaction costs of basic interaction between its participants. A business ecosystem, on the other hand, optimizes only the auxiliary processes of enterprises. In this case, production itself can remain in physical space. The main thing here is that the center of the cluster, which unites organizations around itself, as the base of their interaction is not physically "tied" to a specific geographic area, but is located in a virtual digital space.

So, a digital cluster is understood as a set of socio-economic entities, the target ("link everything, element - nothing") sustainable interaction of which is based on digital technologies that reduce transaction costs. Technological changes transform the patterns of cluster formation. First of all, the place of attraction of key production processes is changing: the cluster includes more and more companies from different regions, information, management and financial transactions between them are carried out in the digital environment. The digital environment provides extreme connectivity - conditions in which time and space barriers between people, people and machines, between machines disappear. As a result, it is the digital environment that is becoming the most important factor in business mergers, which is more important than geographic proximity. Therefore, the totality of economic entities, whose interaction is based on digital technologies that reduce transaction costs, is quite stable.

The creation of a digital business ecosystem is in line with the Industry 4.0 Program, as it provides for the renewal of all intellectual and physical assets involved in the value chain, based on end-to-end technologies from big data to virtual and augmented reality. Industry 4.0 is not only and not so much the current trend in the development of automation and data exchange, which includes cyber-physical systems, the Internet of things and cloud computing. It is also a new level of production organization and value chain management. For the digital transformation of a cluster, such characteristic of Industry 4.0 as digitalization and the integration of vertical and horizontal value chains within the entire organization is significant. Augmented reality technologies are used, data is optimized for specific platforms.

Attention is shifting from the conventionally understood industry to the real possibility of separating the management from physical (tangible) assets. The development of Industry 4.0 digital technologies leads to the separation of information and management processes from automated material production. The personnel engaged in intellectual labor tends to live in territories with a high standard of living, and they organize material production in territories with inexpensive resources.

The main resource required for the formation of a digital cluster is the professional knowledge of workers. Close proximity between people and industries are less and less required for transforming knowledge into innovation in the digital economy. The management of time and space, the key components of the digital stage of the knowledge economy, is actual. Therefore, the intellectual basis of a digital cluster is formed not where there are the required material resources, but where the standard of living is higher and where human potential can be fulfilled in the best way. Digital brand management of the territory plays a significant role in these conditions: it becomes an imperative of professional activity for the younger generation of workers.

The competition between the entities of the digital cluster is based on the competition of the knowledge of their employees, therefore, due to the cohesion, it acquires the properties of scientific cooperation. The basis of the digital economy as a stage of the knowledge economy is the scientific and professional knowledge of workers. The region's mineral resource enterprises operate in conditions of an acute shortage of highly qualified personnel. The development of human potential as the most important component of sustainable development is impossible without digitalization of the scientific and 
educational process in the region. Institutions of science and education should enter the business ecosystem on equal partnership terms.

The issue of the architecture of the system for regulating economic relations in a digital cluster in terms of the choice between hierarchy and etharchy will most likely be decided in favor of the latter. In the trend of humanizing the digital environment, the new mentality of managers and workers is of great importance. A socio-cultural atmosphere must be created that allows to combine the Industry 4.0 advantages with the achievements of digital humanities: readiness for change and interaction at all levels. In a cluster, this can be achieved through etharchical management.

In order to achieve the goals of sustainable development in a resource-extracting region, it is important that Industry 4.0 provides for a reduction in the anthropogenic impact on the environment, rational use of natural resources, recycling of all waste and obtaining new raw materials, energy or a product from it. The cluster "Integrated coal and industrial waste processing" has been operating in the coal industry of Kuzbass officially since 2012, and in fact since 2007. Today, with the development of digital technologies, stricter environmental requirements, changes in state priorities in waste processing, it is intended to be a testing ground for the same-name direction of the Industry 4.0 Program implementation in the coal industry due to its promising digital technologies: the Internet of things in coal preparation, processing and waste; "Smart concentration plant"; coal chemistry technologies for obtaining products with high added value; the use of nano- and biotechnology. The main idea of the Cluster is to supplement the value chain with the deep processing of coal. Its goal is to create and implement cost-effective and environmentally friendly advanced technologies for coal processing and waste disposal with the simultaneous generation of heat, electricity and useful products. Among the named problems of the Cluster's functioning is the existing territorial location of its enterprises in several agglomerations of the region, the time to overcome the distance between which exceeds one hour. This "problem" is being solved today with the help of digital technologies.

\section{Conclusion}

Based on the conducted comparative analysis, a preliminary conclusion about the essential proximity of a digital cluster to a business ecosystem as a progressive form of organization of territorial and sectoral management can be drawn. The negative consequences of the unstable raw material export model of the economy of the Kemerovo Region - Kuzbass, formed over many years, can be overcome on the basis of the sustainable development ideology, since it is determined by the harmonization of natural and socio-economic systems. A systems approach to the sustainable development strategy as the unity and balance of the social, environmental and economic development of a region implies the use of a tool (management model) of business ecosystems, adapted to the digital economy. Digitalization of the mineral resource cluster of the leading coal mining area can and should become a trigger for the acceleration of innovative development of the entire socioeconomic system of the region. This will require the accumulation of empirical data on the readiness of the mineral resource complex for the adaptation to the business ecosystem development format and their quantitative analysis. The theoretical provisions of the transition from the conventional cluster to the business ecosystem of the regional economy, formulated in the work on the basis of the concept of sustainable development, can, in our opinion, be taken into account when substantiating the digitally updated cluster policy, and the digitalization policy of the coal mining region in general. 


\section{References}

1. G. B. Kleiner, Vopr. Ekon., 1, 73 (2021)

2. P. J. H. Schoemaker, P.E. Tetlock, MIT Sloan Manag. Rev., 58(3), 28 (2017)

3. M.E. Porter, Harv. Bus. Rev., 76(6), 77 (1998)

4. Y. Temouri, V. Pereira, G.W. Muschert, V. Ramiah, M. Babula, J. Intellect. Cap., 22(1), 171 (2021)

5. V. Alcacer, V. Cruz-Machado, Eng. Sci. Technol. Int. J., 22(3), 899 (2019)

6. D. Perakovic, M. Perisa, I. Cvitic, P. Zoric, 4th EAI International Conference on Management of Manufacturing Systems. EAI/Springer Innovations in Communication and Computing, 111 (Springer, Cham, 2020)

7. D. J. Teece, Strateg. Manag. J., 28(13), 1319 (2007)

8. J. F. Moore, Harv. Bus. Rev., 71(3), 75 (1993)

9. P. Krugman, J. Polit. Econ., 99(3), 483 (1991)

10. M. J. Enright, World link, 5, 24 (1992)

11. D. B. Audretsch, M. P. Feldman, Rev. Ind. Organ., 11(2), 253 (1996)

12. M. Storper, The regional world: territorial development in a global economy (Guilford Press, New York, 1997).

13. M. Götz, B. Jankowska, Eur. Plan. Stud., 25(9), 1633 (2017)

14. S. A. Dyatlov, N.I. Didenko, O.S. Lobanov, S.V. Kulik, IOP Conf. Ser.: Earth Environ. Sci., 302(1), 012102 (2019)

15. J. S. Brown, P. Duguid, Manag. Learn., 33(4), 427 (2002)

16. C. Mason, T. Castleman, C. Parker, J. Enterp. Inf. Manag., 21(6), 571 (2008)

17. M. Muresan, Metal. Int., 14, 139 (2009)

18. R. U. Ayres, Ecol. Econ., 48(4), 425 (2004) 